\title{
Invasive Marine and Estuarine Animals of Hawai'i and other Pacific Islands
}

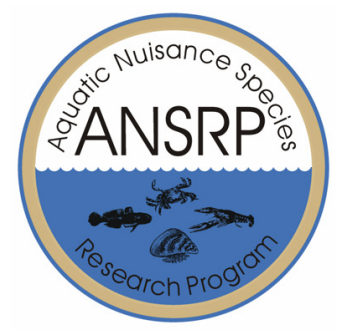

by Gary L. Ray

PURPOSE: Nonnative species of estuarine and marine animals are inadvertently or intentionally introduced into the waters of the United States every year (Figure 1). Variously referred to as introduced, nonindigenous (NIS), alien, nonnative, or exotic species, most pose little or no threat; however, a few have the potential to disrupt local ecosystems, fisheries, and human infrastructure. Such invasions can directly impact the mission of the U.S. Army Corps of Engineers (USACE) through its responsibilities for construction and maintenance of harbors, ports and waterways, erosion control, management of water resources, and wetland and coastal habitat restoration. The general biology and ecology of invasive estuarine and marine animals have been described in previous works (Carlton 2001, Ray 2005). This report is part of a series describing known invasive estuarine and marine animals in the major geographic regions of the United States. Invasive animals of Hawai' $i$ and other Pacific islands are described and examples of species posing a specific threat to USACE activities are identified.

BACKGROUND: Invasive species are officially defined as "alien species whose introduction does or is likely to cause economic or environmental harm to human health" (Executive Order 13112, Federal Register 1999). Any species removed from its native range has the potential to become invasive. This is because within its normal range, predation, disease, parasites, competition, and other natural controls act to keep population levels in check (Torchin et al. 2003, Wolfe 2002). Once released from these controls, species abundances have the potential to reach levels that interfere with or displace local fauna. Such effects

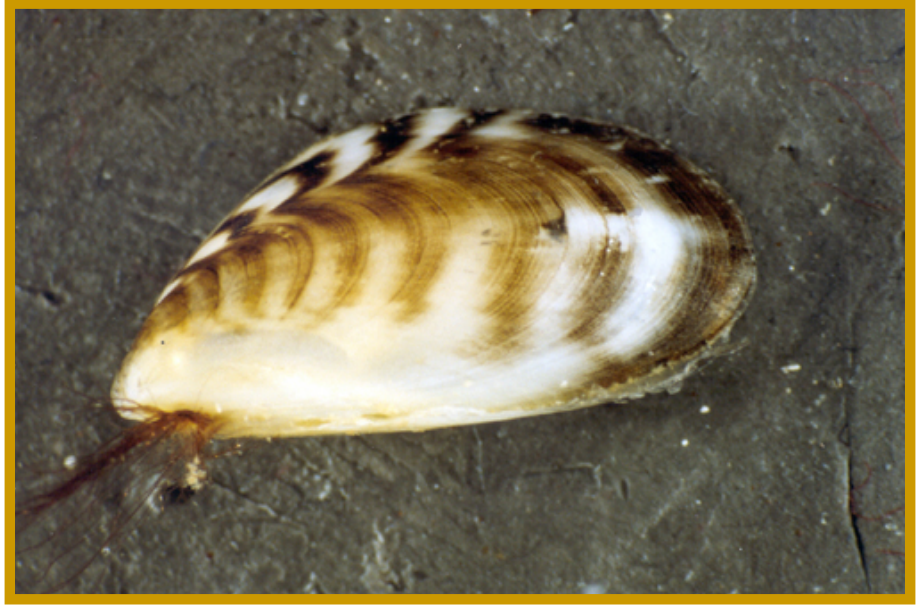

Figure 1. Example of a nonindigenous species, the black-striped mussel Mytilopsis sallei (image courtesy of CRIMP, CSIRO Marine Research) may occur immediately, after some period of delay, or never be realized at all depending on the characteristics of the individual species and the conditions into which it is introduced.

Lists of estuarine and marine nonindigenous species are often dominated by mollusks, crustaceans, and polychaete worms; however, this may reflect their ease of identification and detection rather than the degree to which they are representative. Ultimately it is an organism's biological characteristics (e.g., reproductive capacity, growth rate) and not its taxonomic affinities that determine if it becomes invasive. Successful invaders tend to be abundant over a large range in their native region, have broad feeding and habitat preferences, wide physiological tolerances, short 
generation times, and high genetic variability (Erlich 1989, Williams and Meffe 1999). Despite the fact that we can identify these characteristics, predicting which species pose the greatest threat remains problematic since many species possess these characters, most are not obvious in their native range, and opportunities for introduction and subsequent likelihood of survival are difficult to assess. The situation is further complicated by difficulty in distinguishing invaders from species with naturally wide distributions and those that are cryptogenic; that is, species whose original distributions are uncertain.

Predicting which habitats are likely to be invaded is much simpler. Invaded habitats tend to have low natural diversity, relatively simple (low-connectance) food webs, and a history of recent natural or anthropogenic disturbance (Williams and Meffe 1999). Estuaries and sheltered coastal areas are among the most invaded habitats, presumably due to the fact that they are naturally disturbed, lowdiversity systems and are historically centers of anthropogenic disturbance associated with navigation, industrial development, and urbanization.

Species are introduced by a variety of different mechanisms; however, most estuarine and marine species introductions are associated with shipping (Ruiz et al. 2000). Species capable of attaching to hard surfaces may be transported on ship hulls, navigational buoys, floatation devices, anchors, chains, ropes, and flotsam or jetsam (Carlton 2001). During the heyday of wooden-hulled ships, wood-borers (e.g., shipworms) and species associated with "dry" ballast such as stones, rock, sand, or other materials were frequently introduced (Carlton and Hodder 1995). Presently, the largest single source of shipping-related introductions is ballast water (Carlton 1985, Lavoie et al. 1999). Ballast water is taken onboard vessels for a variety of purposes related to ship maneuverability and control (Carlton et al. 1995). Animals suspended in the water column or present in bottom sediments are taken in and then introduced to a new location when the ballast is pumped out.

Recently, concerns have also been raised regarding introductions of fish, invertebrates, and "live" rock from the aquarium trade (Padilla and Williams 2004, Weigle et al. 2005). The lionfish Pterois volitans may have been introduced into Atlantic waters when a private aquarium was demolished in the Miami area in 1992 during Hurricane Andrew (Hare and Whitfield 2003). Other introductions may result from accidental release of animals, inappropriate disposal of packing material by restaurants serving live seafood, and by the live bait industry. Many species have been deliberately introduced to develop new fisheries. For example, the Atlantic striped bass Morone saxatilis has been introduced both outside its normal geographic range and in nonnative habitats (e.g., landlocked freshwater reservoirs) in much of the United States.

METHODS: Lists of invasive species in Hawai'i and other Pacific Islands were prepared by querying NISBase, a national database of NIS listings maintained by the Smithsonian Institution (http://www.nisbase.org/nisbase/index.jsp). Part of the National Exotic Marine and Estuarine Species Information System (NEMESIS), this database permits simultaneous searches of multiple NIS listings. Searches return up to 300 species and include links to individual species' fact sheets and collection data. Queries were performed by state and included searches of the U.S. Geological Survey's Nuisance Aquatic Species (NAS) database (http://nas.er.usgs.gov/), Australia's National Introduced Pest Species Information System (http://www.marine.csiro.au/crimp/nimpis/), and the Introduced Marine Species of Hawai'i Guidebook (Eldredge and Smith 2001). The resulting lists were examined and separate lists of only estuarine and marine animals were prepared. Cryptogenic 
species were excluded from consideration due to the uncertainty of their origins. These lists were amended as necessary after comparison with individual state NIS listings and other reports (Table 1).

Of particular note among these sources are the technical reports of the Bishop Museum (Coles et al. 1997, 1999, 2001, 2002a, 2002b, 2004a, 2004b; Godwin et al. 2004). The museum has also produced a well-illustrated guidebook to invertebrate NIS (Eldredge and Smith 2001). Copies of all of these reports can be downloaded from the Bishop Museum website (http://hbs.bishopmuseum.org/hbspubs.html).

RESULTS: NIS listings for Hawai'i include a total of 293 species (Table 2). The island of Guam shares 34 of these species (Paulay et al. 2002, Smith 1987) and Johnson Atoll shares 5 species (Coles et al. 2001). The largest numbers of species were found among molluscs (72 species), crustaceans (70 species), and fish (38 species). Many of the fish, in particular, represent deliberate introductions. Randall (1987) reviewed the history of these introductions to Hawai' $i$ and concluded that most of the efforts to introduce marine species were unsuccessful. Only the blacktail snapper Lutjanus fulvus appears to have established selfsustaining populations.

DISCUSSION: Marine and estuarine animals generally considered to be invasive in the state of Hawai'i are the sponges Mycale armata and Sigmadocia caerulea, Christmas tree hydroid Pennaria distica, Snowflake coral Carijoa riisei, Caribbean barnacle Cthamalus proteus, the bryozoans Amthia distans and Schizoporella errata, the tunicate Didemnum candida, and the Philippine mantis shrimp Gonodactylus falcatus (Yamamoto et al. 2003). A number of invasive species not presently found in Hawai'i or other Pacific islands, but likely candidates for introduction, include Chinese mitten crab Eriocheir sinensis, European green crab Carcinus maenas, Mediterranean blue mussel Mytilus galloprovincialis, Asian green (or green-lipped) mussel Perna viridis, Asian date mussel Musculista senhousia, and black striped mussel Mytilopsis sallei (Yamamoto et al. 2003).

\begin{tabular}{|l||}
\hline Table 1 \\
State NIS Listings and Other Reports \\
Utilized in This Report \\
\hline \hline Coles et al. 1997, 1999, 2001, 2002a, 2002b, 2004a, 2004b \\
\hline Eldredge and Smith 2001 \\
\hline Godwin et al. 2004 \\
\hline Randall (1987) \\
\hline State of Hawai'i (2003) \\
\hline
\end{tabular}

\begin{tabular}{|c|c|c|c|}
\hline \multicolumn{4}{|c|}{$\begin{array}{l}\text { Table } 2 \\
\text { Summary NIS Results for Hawai'i } \\
\text { and Other Pacific Islands }\end{array}$} \\
\hline Group & Hawai'i & Guam & Johnson Atoll \\
\hline Protozoan & 3 & & \\
\hline Hydrozoan & 13 & 5 & 1 \\
\hline Cubozoan & 1 & & \\
\hline Schyphozoa & 4 & & \\
\hline Anthozoa & 6 & & \\
\hline Ctenophora & 1 & & \\
\hline Porifera & 12 & & \\
\hline Platyhelminth & 4 & & \\
\hline Nematode & 1 & & \\
\hline Polychaete & 23 & 1 & \\
\hline Bivalve & 38 & 5 & \\
\hline Gastropod & 32 & 3 & \\
\hline Nudibranch & 2 & & \\
\hline Barnacle & 8 & 3 & \\
\hline Copepod & 4 & & \\
\hline Amphipod & 18 & & \\
\hline Isopod & 10 & & \\
\hline Tanaid & 1 & & \\
\hline Cumacea & 2 & & \\
\hline Mysid & 1 & & \\
\hline Pyncnogonid & 2 & & \\
\hline Crab & 15 & & \\
\hline Shrimp & 7 & 3 & \\
\hline Stomatopod & 2 & & \\
\hline Bryozoan & 18 & 1 & 1 \\
\hline Entoproct & 1 & & \\
\hline Tunicate & 26 & 12 & 3 \\
\hline Fish & 38 & 1 & \\
\hline Grand Total & 293 & 34 & 5 \\
\hline
\end{tabular}


Potential Threats to Infrastructure: More than 30 percent of all NIS in Hawai'i and all but one (G. falcatus) of the priority NIS are fouling species. Most likely introduced on ships' hulls or in ballast water, they include 13 species of hydrozoans, 6 anemones, 8 barnacles, 3 bryozoans, 1 entoproct, 26 tunicates, 16 polychaetes, and several bivalves (Appendix A). Over 63 percent of NIS encountered at Guam and all NIS found at Johnson Island are fouling organisms. Because of their potential to clog coastal structures such as intake pipes, members of this group may interfere with USACE operations.

Wood-boring species. Wood-boring species such as shipworms, a form of bivalve mollusc, and small isopods commonly known as gribbles are also a potential threat to infrastructure. Shipworms do not actually feed on wood, but form extensive burrow systems in any submerged wooden structure (e.g., boats, marinas, docks, and pilings). Species known to be present in Hawai'i are the Blacktip shipworm, Lyrodus pedicellatus, and three species in the genus Teredo (T. barstschi, T. clappi, and T. furcifera). Shipworms were reportedly responsible for $\$ 615$ million in damage in San Francisco Bay during an outbreak in the 1920's (Cohen and Carlton 1995). Severe damage was also reported in Barnegat Bay, New Jersey and Long Island Sound, New York after outbreaks of T. bartschi (Hoagland 1983). These pests can be effectively controlled by chemical treatment (e.g., creosote) or use of alternative construction materials (Highley 1999).

While creosote deters shipworm infestations, the same cannot be said of gribbles. Gribbles are able to burrow into treated wood and may even derive nutrition from bacteria in their gut that break down creosote hydrocarbons (Zachary et al. 1983). Recently, engineers with the City of Seattle discovered that a seawall and its wooden supports along the Seattle waterfront are so damaged by gribbles that collapse of the structure is a real possibility. Replacement costs are estimated at $\$ 700$ million (Roach 2004). The Mediterranean gribble Limnoria tripunctata is the only species now reported from Hawai'i.

Chinese mitten crab. Although not presently established in Hawai'i, the Chinese mitten crab Eriocheir sinensis has been shown to be a threat to infrastructure worldwide. It first appeared as an invasive species in Germany during the early 1900's and has since spread through most of Europe (Clark et al. 1998). In the United States it has been reported from Lake Erie, the Columbia River, Mississippi Sound, and San Francisco Bay. Mitten crabs are catadromous, spending most of their adult life in fresh water, then returning to the sea to reproduce (Veldhuizen and Stanish 2002). The adults can live up to 5 years and are omnivorous. Their planktonic larvae grow best in relatively high salinities ( $25 \mathrm{ppt})$, while late stage or megalopal larvae prefer 15 to $25 \mathrm{ppt}$. Late-stage larvae settle out of the plankton in late spring and early summer as they metamorphose into early juvenile stages. They then begin to migrate towards the fresher portions of the estuary. They are most abundant along steep clay banks just below the root zone of adjacent vegetation. Their extensive burrows weaken riverbanks and earthen water control structures leading to severe erosion. The crab population in San Francisco Bay has disrupted fish salvage operations (e.g., the collection of fish at water control structures during drawdowns) and commercial fisheries (Culver and Walter 2001, Wynn and Liston 1999). There is also a potential threat to human health because this species harbors the parasitic Chinese lung fluke. Thus far no flukes have been detected in U.S. crab populations (National Oceanographic and Atmospheric Administration (NOAA), Sea Grant News, 2001). A draft national management plan for E. sinensis promulgated by the Aquatic Nuisance Species Task Force (2002) focuses primarily upon early detection. A variety of potential control methods have been suggested 
including active trawling for adults during the reproductive phase. Culver and Walter (2001) claim some success with a passive system that traps the crabs as they migrate into the estuary. The life history of the Japanese mitten crab (E. japonicus), another invasive species, is believed to be similar. Further information on mitten crabs can be found in Veldhuizen and Stanish (2002), Ray (2005), and an ANSRP fact sheet (http://el.erdc.usace.army.mil/ansrp/eriocheir_sinensis.htm).

Asian green mussel. The Asian green or green-lipped mussel Perna viridis is another invasive species not currently present in Hawai' $i$, but considered to be a threat if it becomes established. A native of the tropical Indo-Pacific, it has spread to Florida and Jamaica (Buddo et al. 2003). Its planktonic larvae are capable of wide dispersal and settle on almost any hard surface. Its discovery in Tampa Bay was due to the fact it was clogging water intake pipes at local power plants (Fuller 2005). It fouls navigation buoys and ship hulls, interferes with shellfish culture, and displaces local fauna. This species also potentially harbors algal species that produce toxic shellfish poisoning (Buddo et al. 2003).

Black striped mussel. The black striped mussel, Mytilopsis sallei (Figure 1), a native of tropical Western Atlantic and Caribbean waters, is a close relative of the infamous zebra mussel (Dreissena polymorpha) and shares many of its invasive qualities. It has already invaded the Indian Ocean and Australia (Hewitt 2002). This species tolerates wide ranges of temperature and salinity, is fast growing, matures within a month of settlement, and produces large numbers of planktonic larvae. It is able to settle on nearly any hard substrate and can form beds up to $15 \mathrm{~cm}$ thick (New South Wales Fishnote 2003). Preferring sheltered habitats, it fouls hulls, pilings, and buoys and can settle in shellfish beds resulting in major damage to aquaculture facilities. Historically, this is one of only two examples where an established marine invader has been eradicated from an invaded site. In 1999, an invasion of Mytilopsis was detected at Darwin Harbor, Australia, in marinas closed off from the surrounding waters by gates. The marinas were quarantined and chemically treated with sodium hypochlorite and copper sulphate. Subsequent monitoring confirmed that the pest had been eradicated (Bax et al. 2002).

\section{Potential Threats to Habitat Restoration:}

Snowflake coral. The Snowflake coral Carijoa riiseri is a Caribbean species that first appeared in Hawai'i in 1972 (Eldredge and Smith 2001). This or a related species may also be present in Chuuk, Federated States of Micronesia (ibid). Coles et al. (2002b) describe it as the most prominent NIS at Waikiki, covering the inner surfaces of a shipwreck, and the principal fouling organism on pilings and other hard surfaces associated with a bridge at Kuapa Pond. Carijoa is also considered a pest species because it overgrows commercially valuable black coral (Antipathes dichotoma and A. grandis), threatening a \$30-million jewelry industry (Grigg and Kelley 2002). Coles et al. (2004a) indicate that both Carijoe and the sponge Mycale armata are increasing in abundance on many coral reefs. Mycale has been reported to be overgrowing coral on some patch reefs (Eldredge and Smith 2001). In both cases, efforts to restore coral reef habitats may be hindered by the spread of these species. The Philippine mantis shrimp Gonodactylus falcatus is also of concern on many coral reefs where it has successfully displaced the native species Pseudosquilla ciliata (Kinzie 1984). 
Caribbean barnacle. The Caribbean barnacle Chthamalus proteus is perhaps the most abundant of Hawai' ian NIS. Native to the Gulf of Mexico, Trinidad, and northeast Brazil, it was probably introduced to Hawai'i sometime in the 1970's (Southward et al. 1998). It reaches high densities in sheltered rocky intertidal areas or pilings. Another hard-bottom invader is the Mediterranean blue mussel Mytilus galloprovincialis. It is found worldwide in temperate seas and along with Chthamalus has the potential to interfere with restoration of rocky intertidal habitats by excluding native species.

Australian spotted jellyfish. An invasive pelagic species is the Australian spotted jellyfish Phylloriza punctata (Figure 2). The spotted jelly has an average adult bell width of $35 \mathrm{~cm}$ and can be found in swarms of up to 500,000 in a $150-\mathrm{km}^{2}$ area. Feeding intensively on zooplankton and fish larvae, they represent a threat to fisheries and fisheries restoration operations.

Another invasive jellyfish is the upside down jelly Cassiopea andromeda, a shallow-water form common in lagoons and intertidal sand flats and mud flats. This species is not a threat to USACE operations, but is considered a nuisance because its nematocysts can deliver a painful sting resulting in welts

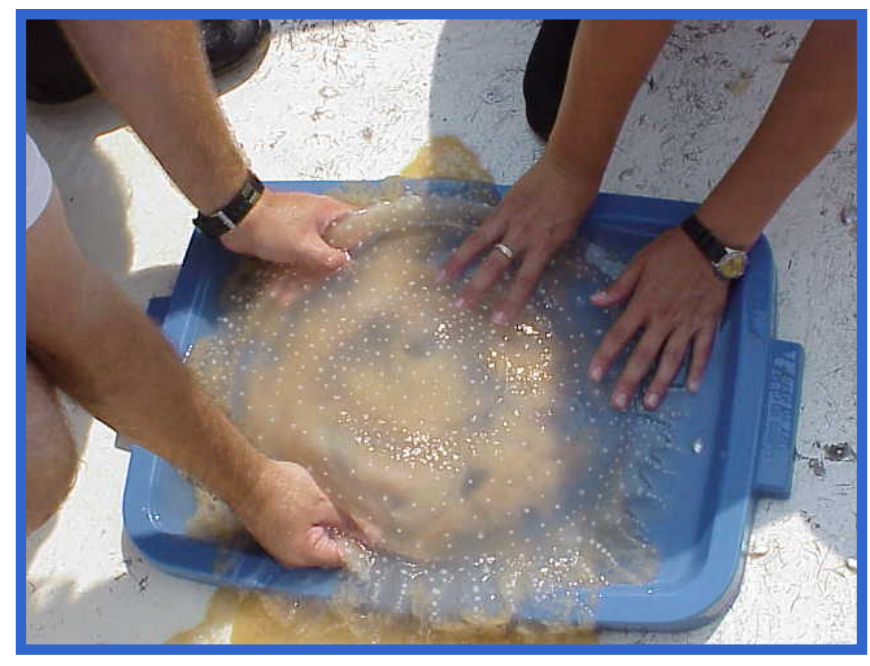

Figure 2. The Australian jellyfish, Phylloriza punctata (image courtesy of Dauphin Island Sea Lab) or a rash (Eldredge and Smith 2001).

European green crab. The European green crab Carcinus maenas has not been found in Hawai'i, but may disrupt habitat restoration efforts if it becomes established. It inhabits a wide range of habitats in sheltered areas including rocky intertidal, unvegetated intertidal and subtidal mud and sand, salt marsh, and seagrass. Capable of tolerating wide ranges of salinity and temperature, it prefers mesohaline to polyhaline salinities (10-30 ppt) and temperatures between $3{ }^{\circ} \mathrm{C}$ and $26{ }^{\circ} \mathrm{C}$ (Grosholz and Ruiz 2002). The green crab was introduced to the east coast of North America sometime in the 1800's (Scattergood 1952) and subsequently invaded the west coast. It has been detected in San Francisco Bay (Cohen et al. 1995) and other California estuaries (Grosholz and Ruiz 1995). It has been reported as far north as Oregon (Miller 1996) and Vancouver Island, Canada (Yamada et al. 2001) and could move into Alaskan waters (Gray Hitchcock et al. 2003). Genetic studies show that the Pacific coast was invaded by east coast populations (Bagley and Geller 1999) with secondary expansion along the west coast attributable to oceanic transport of the planktonic larvae (Yamada et al. 2001). Larvae take approximately 90 days to develop, metamorphose, and settle out in mussel beds, eelgrass beds, or patches of filamentous algae (Moksnes 2002). Older juveniles actively migrate to mussel beds.

Juvenile crabs feed primarily on detritus, then shift to algae, snails, bivalves, annelids, crustaceans, and other benthic organisms as they age (Pihl 1985, Ropes 1968). Predation on both natural and cultured bivalve populations has led to declines in softshell clams (Mya arenaria) in New England 
(Glude 1955), Nutricola spp. in Central California (Grosholz et al. 2000), and the venerid clam Katelysia scalarum in Tasmania (Walton et al. 2002, Ross et al. 2004). It may also outcompete the Dungeness crab Cancer magister for food; however, their habitats generally do not overlap (McDonald et al. 2001). Control measures have generally been unsuccessful and limited to trapping. For more information on this species, see Ray (2005) and Grosholz and Ruiz (2002).

Asian date mussel. Another potential invader is the Asian date mussel Musculista senhousia. Native to intertidal and subtidal sediments from Siberia to the Red Sea, it is now found in Australia, New Zealand, the eastern Mediterranean, and southern France (Crooks 1996). Probably introduced into the United States in 1924 during the intentional introduction of Japanese oysters to Samish Bay, Washington, it has since spread as far as Southern California most likely via ballast water. Its planktonic larvae can remain in the water column as long as 55 days, then settle out on either muddy or sandy substrates. It forms dense beds that significantly alter nearby sediments and native benthic assemblages (Crooks 1996, 1998; Crooks and Khim 1999). Since dredged material is often comprised of soft sediments, this species may interfere with the natural recolonization of dredged material deposits or sediments employed in beneficial use projects. Transplantation success of seagrass restoration projects may also be reduced in infested areas (Reutsch and Williams 1998). Ironically, dense, intact beds of native seagrass directly inhibit the growth of Musculista populations by limiting availability of phytoplankton within the bed (Allen and Williams 2003).

ACKNOWLEDGEMENTS: This review was sponsored by the U. S. Army Engineer Research and Development Center, Vicksburg, MS, under the Aquatic Nuisance Species Research Program (ANSRP).

POINTS OF CONTACT: For additional information contact Dr. Gary L. Ray (601-634-2589, Gary.Ray@erdc.usace.army.mil) or the Program Manager of the Aquatic Nuisance Species Research Program (ANSRP), Mr. Glenn Rhett (601-634-3717), Glenn.G.Rhett@,erdc.usace.army.mil. This technical note should be cited as follows:

Ray, G. L. (2005). "Invasive estuarine and marine animals of Hawai'i and other Pacific Islands," ANSRP Technical Notes Collection (ERDC/TN ANSRP-05-3), U.S. Army Engineer Research and Development Center, Vicksburg, MS. http://el.erdc.usace.army.mil/ansrp

\section{REFERENCES}

Allen, B. J., and Williams, S. L. (2003). "Native eelgrass Zostera marina controls growth and reproduction of an invasive mussel through food limitation," Marine Ecology Progress Series 254, 57-67.

Aquatic Nuisance Species Task Force. (2002). “A draft national management plan for the genus Eriocheir,” Report of the Chinese Mitten Crab Control Committee. Available online at http://anstaskforce.gov/.

Bagley, M. J., and Geller, J. B. (1999). "Microsatellite DNA analysis of native and invading populations of European green crabs." First National Conference on Marine Bioinvasions. January 24-27, 1999. Cambridge, MA. Available online at: http://massbay.mit.edu/exoticspecies/conferences/1999. 
Bax, N., Hayes, K., Marshall, A., Parry, D., and Thresher, R. (2002). "Man-made marinas as sheltered islands for alien organisms: Establishment and eradication of an alien invasive marine species." Turning the tide: The eradication of invasive species. C. R. Veitch and M. N. Clout, ed. IUCN SSC Invasive Species Specialist Group, IUCN, Gland, Switzerland and Cambridge, UK, 26-39.

Buddo, D. St. A., Steele, R. D., and D’Oyen, E. R. (2003). “Distribution of the invasive indo-pacific green mussel, Perna viridis, in Kingston Harbour, Jamaica." Bulletin of Marine Science 73, 433-441.

Carlton, J. T. (1985). "Transoceanic and intraoceanic dispersal of coastal marine organisms: The biology of ballast water," Oceanography and Marine Biology: An Annual Review 23, 313-374.

Carlton, J. T. (2001). Introduced species in U.S. coastal waters: Environmental impacts and management priorities. Pew Oceans Commission. Arlington, VA. Available online at $h t t p: / / w w w . p e w t r u s t s . o r g / p d f / e n v \_o c e a n s \_s p e c i e s . p d f$.

Carlton, J. T., and Hodder, J. (1995). "Biogeography and dispersal of coastal marine organisms: Experimental studies on a replica of a $16^{\text {th }}$ century sailing vessel," Marine Biology 121, 721-730.

Carlton, J. T., Reid, D. M., and van Leeuwen, H. (1995). Shipping study. The role of shipping in the introduction of nonindigenous aquatic organisms to the coastal waters of the United States (other than the Great Lakes) and an analysis of control options. The National Sea Grant College Program/Connecticut Sea Grant Project R/ES-6. Report No. CG-D-11-95.

Clark, P. F., Rainbow, P. S., Robbins, R. S., Smith, B., Yeomans, W. E., Thomas, M., and Dobson, A. G. (1998). "The alien Chinese mitten crab, Eriocheir sinensis (Crustacea: Decapoda: Brachyura), in The Thames catchment," Journal of the Marine Biological Association of the United Kingdom 78, 1215-1221.

Cohen, A. N., and Carlton, J. T. (1995). Biological study. Nonindigenous aquatic species in a United States estuary: A case study of the biological invasions of the San Francisco Bay and Delta. A report for the United States Fish and Wildlife Service, Washington, DC and the National Sea Grant Program, Connecticut Sea Grant Publication PB96166525. Available online at $h t t p: / / w w w . a n s t a s k f o r c e . g o v / s f i n v a d e . h t m$.

Cohen, A. N., Carlton, J. T., and Fountain, M. C. (1995). "Introduction, dispersal and potential impacts of the green crab Carcinus maenas in San Francisco Bay, California," Marine Biology 122, 225-237.

Coles, S. L., DeFelice, R. C., and Eldredge, L. G. (1999). "Nonindigenous marine species introductions in the harbors of the south and west shores of Oahu, Hawai'i," Bishop Museum Technical Report 15, Bernice Pauahi Bishop Museum. Available online at $h t t p: / / h b s . b i s h o p m u s e u m . o r g / h b s p u b s . h t m l$.

Coles, S. L., DeFelice, R. C., and Eldredge, L. G. (2002a). "Nonindigenous marine species in Kane'ohe Bay, O'ahu, Hawai'i," Bishop Museum Technical Report 24, Bernice Pauahi Bishop Museum. Available online at http://hbs.bishopmuseum.org/hbspubs.html.

Coles, S. L., DeFelice, R. C., and Eldredge, L. G. (2002b). "Nonindigenous marine species at Waikiki and Hawai'i Kai, O'ahu, Hawai'i Bay," Bishop Museum Technical Report 25, Bernice Pauahi Bishop Museum. Available online at http://hbs.bishopmuseum.org/hbspubs.html.

Coles, S. L., DeFelice, R. C., and Minton, D. (2001). "Marine species survey of Johnson Atoll, Central Pacific Ocean, June 2000," Bishop Museum Technical Report 19, Bernice Pauahi Bishop Museum. Available online at http://hbs.bishopmuseum.org/hbspubs.html.

Coles, S. L., DeFelice, R. C., Eldredge, L. G., and Carlton, J. T. (1997). "Biodiversity of marine communities in Pearl Harbor, Oahu, Hawai'i with observations on introduced exotic species," Bishop Museum Technical Report 10, Bernice Pauahi Bishop Museum. Available online at http://hbs.bishopmuseum.org/hbspubs.html. 
Coles, S. L., Eldredge, L. G., Kandel, F., Reath, P. R., and Longenecker, K. (2004a). “Assessment of nonindigenous species on coral reefs in the Hawai'ian Islands with emphasis on introduced invertebrates," Bishop Museum Technical Report 27, Bernice Pauahi Bishop Museum. Available online at http://hbs.bishopmuseum.org/ hbspubs.html.

Coles, S. L., Reath, P. R., Longenecker, K., Bolick, H., and Eldredge, L. G. (2004b). “Assessment of nonindigenous marine species in harbors and on nearby coral reefs on Kaua'i, Moloka'i, Maui, and Hawai'i," Bishop Museum Technical Report 29a, Bernice Pauahi Bishop Museum. Available online at http://hbs.bishopmuseum.org/ hbspubs.html.

Crooks, J. A. (1996). "The population ecology of an exotic mussel, Musculista senhousia, in a Southern California bay," Estuaries 19, 42-50.

Crooks, J. A. (1998). "Habitat alteration and community-level effects of an exotic mussel, Musculista senhousia," Marine Ecology Progress Series 162, 137-152.

Crooks, J. A., and Khim, H. S. (1999). "Architectural vs. biological effects of a habitat-altering, exotic mussel, Musculista senhousia," Journal of Experimental Marine Biology and Ecology 240, 53-75.

Culver, C. S., and Walter, M. H. (2001). "Prospective management of the Chinese mitten crab: Evaluation of a passive trapping system." Second International Conference on Marine Bioinvasions. April 9-11, 2001. New Orleans, LA. Available online at http://massbay.mit.edu/exoticspecies/conferences/2001.

Eldredge, L. G., and Evenhuis, N. L. (2002). "Numbers of Hawai'ian species for 2000." Records of the Hawai' $i$ Biological Survey for 2000. Bishop Museum Occasional Papers 68, 71-78.

Eldredge, L. G, and Smith, C. M., ed. (2001). “A guidebook of introduced marine species in Hawai'i," Bishop Museum Technical Report 21, Bernice Pauahi Bishop Museum. Available online at http://www2.bishopmuseum.org/HBS/invertguide/species_pdf/guide.pdf.

Erlich, P. R. (1989). "Attributes of invaders and the invading processes: Vertebrates." Chapter 13, Biological invasions: A global perspective. J. A. Drake, et al., ed. 1989 SCOPE. John Wiley and Sons, Ltd, 315-328. Available online at http://www.icsu-scope.org/downloadpubs/scope37/scope37.html.

Federal Register. (1999). Executive Order 13112 of February 3, 1999-Invasive Species. Federal Register 64, No. 25. Available online at $h t t p: / / w w w . i n v a s i v e s p e c i e s . g o v / l a w s$.

Fuller, P. (2005). Phyllorhiza punctata. Nonindigenous Aquatic Species Database, Gainesville, FL. http://nas.er.usgs.gov/queries/FactSheet.asp?SpeciesID=1192.

Glude, J. B. (1955). "The effects of temperature and predators on the abundance of the soft-shell clam, Mya arenaria, in New England," Transactions of the American Fisheries Society 84, 13-24.

Godwin, L. S., Eldredge, L. G., and Gant, K. (2004). "The assessment of hull fouling as a mechanism for the introduction of marine alien species in the main Hawai'ian Islands," Technical Report 28, Bernice Pauahi Bishop Museum. Available online at http://hbs.bishopmuseum.org/hbspubs.html.

Gray Hitchcock, N., Teck, S., Lipski, D., Steves, B., de Rivera, C. and Ruiz, G. (2003). "Predicting European green crab, Carcinus maenas, invasion in Alaska." Third International Conference on Bioinvasions. March 16-19, 2003. Available online at $h t t p: / / m a s s b a y . m i t . e d u / e x o t i c s p e c i e s / c o n f e r e n c e s / 2003$.

Grigg, R., and Kelley, C. (2002). "Sustainability of the black coral fishery in Hawai'i and impacts on bottomfish habitat," National Undersea Research Center for Hawai'i and the Western Pacific-Q4 2002 Milestone Report. National Undersea Research Center for Hawai'i and the Western Pacific. Available online at http://www.soest.Hawai'i.edu/HURL/Q4_2002.html. 
Grosholz, E. D., and Ruiz, G. M. (1995). "Spread and potential impact of the recently introduced European green crab Carcinus maenas, in Central California," Marine Biology 122, 239-247.

Grosholz, E., and Ruiz, G., ed. (2002). "Management plan for the European green crab," Submitted to the Aquatic Nuisance Species Task Force. March 1, 2002. Available online at http://anstaskforce.gov/.

Grosholz, E. D., Ruiz, G. M., Dean, C. A., Shirley, K. A., Maron, J. L., and Connors, P. G. (2000). "The impacts of a nonindigenous marine predator in a California bay," Ecology 81, 1206-1224.

Hare, J. A., and Whitfield, P. E. (2003). "An integrated assessment of the introduction of Lionfish (Pterois volitans/miles complex) to the Western Atlantic Ocean," National Atmospheric and Oceanographic Administration, National Ocean Service Technical Memorandum CCFHR 1.

Hewitt, C. L. (2002). "Distribution and biodiversity of Australian tropical marine Bioinvasions." Pacific Science 56, 213-222.

Highley, T. L. (1999).."Biodeterioration of wood." Chapter 13, Wood handbook--Wood as an engineering material. Gen. Tech. Rep. FPL-GTR-113, U.S. Department of Agriculture, Forest Service, Forest Products Laboratory, Madison, WI. Available online at http://www.fpl.fs.fed.us/documnts/fplgtr/fplgtr113/ch13.pdf.

Hoagland, K. E. (1983). Life history characteristics and physiological tolerances of Teredo bartschi, a shipworm introduced into two temperate zone nuclear power plant effluents. Hemisphere Publishing Co., Miami Beach, FL, 609-622.

Kinzie, R. A. (1984). "The ecology of replacement of Pseudosquilla ciliata by Gonodactylus falcatus (Crustacea: Stomatopoda) recently introduced into the Hawai'ian Islands," Pacific Science 22, 465-475.

Lavoie, D. M., Smith, L. D., and Ruiz, G. M. (1999). "The potential for intracoastal transfer of nonindigenous species in the ballast water of ships," Estuarine, Coastal and Shelf Science 48, 551-654.

McDonald, P. S., Jensen, G. C., and Armstrong, D. A. (2001). "The competitive and predatory impacts of the nonindigenous crab Carcinus maenas (L.) on early benthic phase Dungeness crab Cancer magister Dana," Journal of Experimental Marine Biology and Ecology 258, 39-54.

Miller, T. W. (1996). "First record of the green crab Carcinus maenas in Humboldt Bay, California," California Fish and Game 82, 93-96.

Moksnes, P.-O. (2002). "The relative importance of habitat-specific settlement, predation, and juvenile dispersal for distribution and abundance of young juvenile shore crabs Carcinus maenas L," Journal of Experimental Marine Biology and Ecology 271, 41-73.

National Oceanographic and Atmospheric Administration (NOAA) Sea Grant News (2001). "Chinese mitten crabs appear free of lung flukes." National Oceanographic and Atmospheric Administration, Sea Grant Current News November 14, 2001. Available online at http://www.seagrantnews.org/news/20011114_chinese.html.

New South Wales Fisheries (2003). "Black-striped mussel, Mytilopsis sallei." New South Wales Fishnote, NSWF1129. Available online at http://www.fisheries.nsw.gov.au/threatened_species/general/content/fn_blackstriped_mussel.htm.

Padilla, D. K., and Williams, S. L. (2004). "Beyond ballast water: Aquarium and ornamental trades as sources of invasive species in aquatic ecosystems," Frontiers in Ecology and the Environment 3, 131-138.

Paulay, G., Kirkendale, L., Lambert, G., and Meyer, C. (2002). "Anthropogenic biotic interchange in a coral reef ecosystem: A case study from Guam," Pacific Science 56, 403-422. 
Pihl, L. (1985). "Food selection and consumption of mobile epibenthic fauna in shallow marine areas," Marine Ecology Progress Series 22, 169-179.

Randall, J. E. (1987). “Introductions of marine fishes to the Hawai'ian Islands," Bulletin of Marine Science 41, 490-502.

Ray, G. L. (2005) "Invasive animal species in marine and estuarine environments: Biology and ecology," Technical Report ERDC/EL TR-05-2, U.S. Army Engineer Research and Development Center, Vicksburg, MS.

Reutsch, T. B. M., and Williams, S. L. (1998). "Variable response of native eelgrass Zostera marina to a nonindigenous bivalve Musculista sehousia," Decologia 113, 428-441

Roach, J. (2004). "Seattle waterfront falling to gribble invasion." National Geographic News. Available online at http://news.nationalgeographic.com/news/2004/04/0423_040423_gribbles_2.html.

Ropes, J. W. (1968). “The feeding habits of the green crab, Carcinus maenas (L.)," Fishery Bulletin 67, 183-203.

Ross, D. J., Johnson, C. R., Hewitt, C. L. and Ruiz, G. M. (2004). "Interaction and impacts of two introduced species on a soft-sediment marine assemblage in SE Tasmania," Marine Biology 144, 747-756.

Ruiz, G. M., Fofonoff, P., Carlton, J. T., Wonham, M. J., and Hines, A. H. (2000). "Invasion of coastal marine communities in North America: Apparent patterns, processes, and biases," Annual Review in Ecology and Systematics 2000, 481-531.

Scattergood, L. W. (1952). "The distribution of the green crab Carcinides maenas (L.), in the Northwestern Atlantic," Maine Department of Sea Shore Fisheries. Fishery Circular 8, 2-10.

Smith, B. D. (1987). "Growth rate, distribution and abundance of the introduced topshell Trochus niloticus Linnaeus on Guam, Mariana Islands,” Bulletin of Marine Science 41, 466-474.

Southward, A. J., Burton, R. S., Coles, S. L., Dando, P. R., DeFelice, R. C., Hoover, J., Parnell, P. E., Yamaguchi, T., and Newman, W. A. (1998). "Invasion of Hawai'ian shores by an Atlantic barnacle," Marine Ecology Progress Series 165, 119-126.

State of Hawai'i (2003). State of Hawai'i Aquatic Nuisance Species (AIS) Management Plan. Department of Land and Natural Resources, Honolulu, HI. Available online at http://www.anstaskforce.gov/mgtplans.htm.

Torchin, M. E., Lafferty, K. D., Dobson, A. P., McKensie, V. J., and Kuris, A. M. (2003). "Introduced species and their missing parasites," Nature 421, 628-630.

Veldhuizen, T., and Stanish, S. (2002). "Overview of the life history, distribution, abundance, and impacts of Chinese mitten crab Eriocheir sinensis." Appendix A, A draft national management plan for the genus Eriocheir. Aquatic Nuisance Species Task Force, February 2002, 37-5. Available online at http://anstaskforce.gov/.

Walton, W. C., MacKinnon, C., Rodriguez, L. F., Proctor, C., and Ruiz, G. M. (2002). "Effect of an invasive crab on a marine fishery: Green crab, Carcinus maenas, predation upon a venerid clam, Katelysia scalarina, in Tasmania (Australia)," Journal of Experimental Marine Biology and Ecology 272, 171-189.

Weigle, S. M., Smith, L. D., Carlton, J. T., and Pederson, J. (2005). "Assessing the risk of introducing exotic species via the live marine species trade," Conservation Biology 19, 213-223.

Williams, J. D., and Meffe, G. K. (1999). "Nonindigenous Species." Status and trends of the nation's biological resources. United States Geological Service. Available online at http://biology.usgs.gov/s+t/SNT/index.htm.

Wolfe, L. M. (2002). "Why alien invaders succeed: Support for the escape-from-enemy hypothesis," American Naturalist 160, 705-711. 
Wynn, S., Hess, L., and Liston, C. (1999). "The invasion of the Chinese mitten crab and its effects on fish protection facilities." First National Conference on Marine Bioinvasions. January 24-27, 1999. Cambridge, MA. Available online at: http://massbay.mit.edu/exoticspecies/conferences/1999.

Yamada, S. B., Kalin, A., and Hunt, C. (2001). "Growth and longevity of the European green crab Carcinus maenas, in the Pacific Northwest." Second International Conference on Bioinvasions, 2001, New Orleans, LA. Available online at $h$ ttp://massbay.mit.edu/exoticspecies/conferences/2001.

Yamamota, M., Eldredge, L., and Cravalho, D. (2003). "State of Hawai'i aquatic nuisance species plan. Priority species - freshwater and marine." Draft Document. Available online at http://lama.kcc.Hawai'i.edu/praise/news/ Priorityspecies_draft2.doc.

Zachary, A., Parrish, K. K., and Bultman, J. D. (1983). Possible role of marine bacteria in providing the creosoteresistance of Limnoria tripunctata," Marine Biology 75, 1-8.

NOTE: The contents of this technical note are not to be used for advertising, publication, or promotional purposes. Citation of trade names does not constitute an official endorsement or approval of the use of such products. 


\section{APPENDIX A: NIS LISTINGS FOR HAWAI'I AND OTHER PACIFIC ISLANDS}

\begin{tabular}{|c|c|c|c|c|c|c|}
\hline Species & Group & State $^{1}$ & NISBase & Bishop $^{2}$ & Guam & Johnson \\
\hline Cephaloidophora communis & Protozoan & ST & & & & \\
\hline Eufolliculina lignicola & Protozoan & ST & & & & \\
\hline Microfolliculina limnoriae & Protozoan & ST & & B & & \\
\hline Clytia hemispherica & Hydrozoan & ST & $\mathrm{HI}$ & B & GU & \\
\hline Bougainvillia muscus & Hydrozoan & ST & & B & & \\
\hline Dynamena cristiodes & Hydrozoan & & $\mathrm{HI}$ & $B$ & & \\
\hline Garveia humilis & Hydrozoan & & $\mathrm{HI}$ & & & \\
\hline Halecium beanie & Hydrozoan & & $\mathrm{HI}$ & & & \\
\hline Halocordyle disticha & Hydrozoan & & & B & & \\
\hline Obelia bidentata & Hydrozoan & ST & $\mathrm{HI}$ & B & & \\
\hline Obelia dichotoma & Hydrozoan & ST & $\mathrm{HI}$ & B & GU & \\
\hline Pennaria (Halocordyle) distichia & Hydrozoan & ST & $\mathrm{HI}$ & B & GU & $\mathrm{J}$ \\
\hline Sarsia tubulosa & Hydrozoan & ST & & & & \\
\hline Synthecium megathecum & Hydrozoan & ST & & B & & \\
\hline Thyroscyphus fruticosus & Hydrozoan & & $\mathrm{HI}$ & & GU & \\
\hline Turritopsis nutricola & Hydrozoan & ST & $\mathrm{HI}$ & B & GU & \\
\hline Carybdea sivickisi & Cubozoan & ST & & & & \\
\hline Aurelia sp. & Schyphozoan & ST & $\mathrm{HI}$ & $B$ & & \\
\hline Cassiopea andromeda & Schyphozoan & ST & $\mathrm{HI}$ & B & & \\
\hline Cassiopea medusa & Schyphozoan & & $\mathrm{HI}$ & B & & \\
\hline Phyllorhiza punctata & Schyphozoan & ST & $\mathrm{HI}$ & B & & \\
\hline Actinodiscus nummiformis & Anthozoan & ST & & B & & \\
\hline Anomalorhiza shawi & Anthozoan & ST & & $B$ & & \\
\hline Carijoa riisei & Anthozoan & ST & $\mathrm{HI}$ & $B$ & & \\
\hline Diadumene franciscana & Anthozoan & ST & $\mathrm{HI}$ & $B$ & & \\
\hline Diadumene leucolena & Anthozoan & ST & $\mathrm{HI}$ & B & & \\
\hline Diadumene lineate & Anthozoan & ST & $\mathrm{HI}$ & B & & \\
\hline Vallicula multifrons & Ctenophora & ST & & $B$ & & \\
\hline Dysidea cf. avara & Poriferan & c & $\mathrm{HI}$ & B & & \\
\hline Dysidea cf. ethereal & Poriferan & & & $B$ & & \\
\hline Dysidea sp. & Poriferan & ST & $\mathrm{HI}$ & $B$ & & \\
\hline Echinodictyum asperum & Poriferan & c & $\mathrm{HI}$ & & & \\
\hline Gelliodes fibrosa & Poriferan & ST & $\mathrm{HI}$ & B & & \\
\hline Halichondria melanadocia & Poriferan & ST & $\mathrm{HI}$ & B & & \\
\hline Mycale (Aegogropila) armata & Poriferan & ST & $\mathrm{HI}$ & B & & \\
\hline Mycale (Camia) Cecilia & Poriferan & ST & $\mathrm{HI}$ & B & & \\
\hline Neofolitispa unguiculata & Poriferan & & $\mathrm{HI}$ & B & & \\
\hline Sigmadocia caerulea & Poriferan & ST & $\mathrm{HI}$ & B & & \\
\hline Suberites zeteki & Poriferan & ST & $\mathrm{HI}$ & $B$ & & \\
\hline Zygomycale parishii & Poriferan & ST & $\mathrm{HI}$ & $B$ & & \\
\hline \multicolumn{7}{|c|}{ (Sheet 1 of 7} \\
\hline
\end{tabular}


ERDC/TN ANSRP-05-3

September 2005

\begin{tabular}{|c|c|c|c|c|c|c|}
\hline Species & Group & State $^{1}$ & NISBase & Bishop $^{2}$ & Guam & Johnson \\
\hline Camallanus cotti & Nematode & ST & & & & \\
\hline Ascocotyle tenuicollis & Platyheminth & ST & & & & \\
\hline Bothriocephalus acheilognathi & Platyheminth & ST & & & & \\
\hline Salsuginus seculus & Platyheminth & ST & & & & \\
\hline Taenioplana teredini & Platyheminth & ST & & $B$ & & \\
\hline Chaetopterus variopedatus & Polychaete & & $\mathrm{HI}$ & & & \\
\hline Circeis cf. armoricana & Polychaete & & & $B$ & & \\
\hline Eulalia sanguinea & Polychaete & ST & & $B$ & & \\
\hline Ficopomarus enigmaticus & Polychaete & ST & $\mathrm{HI}$ & B & & \\
\hline Hydroides branchacantha & Polychaete & ST & $\mathrm{HI}$ & B & & \\
\hline Hydroides crucigera & Polychaete & ST & $\mathrm{HI}$ & B & & \\
\hline Hydroides dirampha & Polychaete & ST & $\mathrm{HI}$ & $B$ & & \\
\hline Hydroides elegans & Polychaete & ST & $\mathrm{HI}$ & $B$ & & \\
\hline Janua pagenstecheri & Polychaete & ST & & $B$ & & \\
\hline Nereis areanacoedentata & Polychaete & ST & $\mathrm{HI}$ & $B$ & & \\
\hline Nereis succinea & Polychaete & ST & & & & \\
\hline Pileolaria militaris & Polychaete & & & B & & \\
\hline Polydora nuchalis & Polychaete & ST & $\mathrm{HI}$ & & & \\
\hline Polydora websteri & Polychaete & ST & $\mathrm{HI}$ & $B$ & & \\
\hline Pomatoceros cf. minutus & Polychaete & & & $B$ & & \\
\hline Pomatoleios kraussi & Polychaete & ST & $\mathrm{HI}$ & $B$ & & \\
\hline Sabellastarte sanctujosephi & Polychaete & & $\mathrm{HI}$ & & & \\
\hline Sabellastarte spectabilis & Polychaete & ST & $\mathrm{HI}$ & B & & \\
\hline Salmacina dysteri & Polychaete & & $\mathrm{HI}$ & $B$ & GU & \\
\hline Salmicina tribranchiata & Polychaete & & & $B$ & & \\
\hline Serpula vermicularis & Polychaete & & $\mathrm{HI}$ & $B$ & & \\
\hline Serpula watsoni & Polychaete & & & B & & \\
\hline Streblospio benedicti & Polychaete & ST & $\mathrm{HI}$ & & & \\
\hline Abra sp. & Bivalve & ST & $\mathrm{HI}$ & B & & \\
\hline Anomia nobilis & Bivalve & ST & $\mathrm{HI}$ & B & GU & \\
\hline Bankia bipalmulata & Bivalve & ST & $\mathrm{HI}$ & & & \\
\hline Chama brassica & Bivalve & & $\mathrm{HI}$ & & & \\
\hline Chama elatensis & Bivalve & ST & & B & & \\
\hline Chama fibula & Bivalve & ST & $\mathrm{HI}$ & $B$ & GU & \\
\hline Chama lazarus & Bivalve & ST & $\mathrm{HI}$ & & GU & \\
\hline Chama macerophylla & Bivalve & & $\mathrm{HI}$ & $B$ & & \\
\hline Chama pacifica & Bivalve & ST & $\mathrm{HI}$ & B & & \\
\hline Clinocardium nuttalli & Bivalve & ST & & & & \\
\hline Crassostrea amasa & Bivalve & ST & $\mathrm{HI}$ & & & \\
\hline Crassostrea commercialis & Bivalve & & $\mathrm{HI}$ & & & \\
\hline Crassostrea gigas & Bivalve & ST & $\mathrm{HI}$ & B & GU & \\
\hline Crassostrea virginica & Bivalve & ST & $\mathrm{HI}$ & B & & \\
\hline Crucibulum spinosum & Bivalve & & $\mathrm{HI}$ & B & & \\
\hline Dendrostrea sandvichensis & Bivalve & & $\mathrm{HI}$ & & & \\
\hline
\end{tabular}




\begin{tabular}{|c|c|c|c|c|c|c|}
\hline Species & Group & State $^{1}$ & NISBase & Bishop $^{2}$ & Guam & Johnson \\
\hline Hiatella arctica & Bivalve & ST & $\mathrm{HI}$ & $\mathrm{B}$ & & \\
\hline Lopha cristigalli & Bivalve & & $\mathrm{HI}$ & & & \\
\hline Lyrodus affinis & Bivalve & ST & $\mathrm{HI}$ & B & & \\
\hline Lyrodus pedicellatus & Bivalve & ST & $\mathrm{HI}$ & B & & \\
\hline Martesia striata & Bivalve & ST & $\mathrm{HI}$ & B & & \\
\hline Meretrix meretrix & Bivalve & ST & & $B$ & & \\
\hline Mya arenaria & Bivalve & ST & & & & \\
\hline Mytilus galloprovincialis & Bivalve & ST & $\mathrm{HI}$ & B & & \\
\hline Ostrea conchaphila & Bivalve & ST & $\mathrm{HI}$ & & & \\
\hline Pinctada furcata martensi & Bivalve & ST & $\mathrm{HI}$ & & & \\
\hline Saccostrea cucullata & Bivalve & ST & & $B$ & & \\
\hline Sphenia luticola & Bivalve & ST & $\mathrm{HI}$ & & & \\
\hline Spehnia sp. & Bivalve & & $\mathrm{HI}$ & B & & \\
\hline Teredo bartschi & Bivalve & ST & $\mathrm{HI}$ & $B$ & & \\
\hline Teredo clappi & Bivalve & ST & & $B$ & & \\
\hline Teredo furcifera & Bivalve & ST & $\mathrm{HI}$ & $\mathrm{B}$ & & \\
\hline Tivela stultorum & Bivalve & ST & & & & \\
\hline Tridacna crocea & Bivalve & ST & $\mathrm{HI}$ & & & \\
\hline Tridacna derasia & Bivalve & ST & & & & \\
\hline Tridacna gigas & Bivalve & & $\mathrm{HI}$ & & & \\
\hline Tridacna squamosa & Bivalve & ST & $\mathrm{HI}$ & & GU & \\
\hline Venerupis (=Tapes) philippanarum & Bivalve & ST & $\mathrm{HI}$ & B & & \\
\hline Amphithalamus inclusus & Gastropod & ST & & & & \\
\hline Boonea cincta & Gastropod & ST & & & & \\
\hline Bulla adamsi & Gastropod & ST & & B & & \\
\hline Crepidula aculeate & Gastropod & ST & $\mathrm{HI}$ & $\mathrm{B}$ & GU & \\
\hline Crucibulum spinosum & Gastropod & ST & $\mathrm{HI}$ & B & GU & \\
\hline Chrysallida trachis & Gastropod & ST & & & & \\
\hline Cypraea clandestine & Gastropod & & $\mathrm{HI}$ & & & \\
\hline Cypraea cribaria & Gastropod & & $\mathrm{HI}$ & & & \\
\hline Cypraea cylindrical & Gastropod & & $\mathrm{HI}$ & & & \\
\hline Cypraea depressa & Gastropod & & $\mathrm{HI}$ & & & \\
\hline Cypraea gaspardi & Gastropod & & $\mathrm{HI}$ & & & \\
\hline Cypraea hirundo & Gastropod & & $\mathrm{HI}$ & & & \\
\hline Cypraea kuroharai & Gastropod & ST & & & & \\
\hline Cypraea poraria & Gastropod & & $\mathrm{HI}$ & & & \\
\hline Diodora ruppelli & Gastropod & ST & $\mathrm{HI}$ & $\mathrm{B}$ & & \\
\hline Eualetes tulipa & Gastropod & ST & & $\mathrm{B}$ & & \\
\hline Evalea sp. & Gastropod & ST & & & & \\
\hline Fossaria viridis & Gastropod & & $\mathrm{HI}$ & & & \\
\hline Haliotis spp. & Gastropod & ST & & B & & \\
\hline Helisoma sp. & Gastropod & & $\mathrm{HI}$ & & & \\
\hline Hinemoa indica & Gastropod & ST & $\mathrm{HI}$ & $\mathrm{B}$ & & \\
\hline Iolea eucosmia & Gastropod & ST & & & & \\
\hline
\end{tabular}


ERDC/TN ANSRP-05-3

September 2005

\begin{tabular}{|c|c|c|c|c|c|c|}
\hline Species & Group & State $^{1}$ & NISBase & Bishop $^{2}$ & Guam & Johnson \\
\hline Ivadella navisa & Gastropod & ST & & & & \\
\hline Melanoides tuberculatus & Gastropod & ST & $\mathrm{HI}$ & & & \\
\hline Pila conica? & Gastropod & & $\mathrm{HI}$ & & & \\
\hline Peristichia pedoroana & Gastropod & ST & & & & \\
\hline Planorbella duryi ? & Gastropod & & $\mathrm{HI}$ & & & \\
\hline Pseudosuccinna columella & Gastropod & & $\mathrm{HI}$ & & & \\
\hline Tarebia granifera & Gastropod & ST & $\mathrm{HI}$ & & & \\
\hline Trochus niloticus & Gastropod & ST & & $B$ & GU & \\
\hline Vermetus alii & Gastropod & & $\mathrm{HI}$ & B & & \\
\hline Vitularia miliaris & Gastropod & & $\mathrm{HI}$ & & & \\
\hline Cuthona perca & Nudibranch & ST & $\mathrm{HI}$ & $B$ & & \\
\hline Okenia pellucida & Nudibranch & ST & & B & & \\
\hline Balanus amphitrite & Barnacle & ST & $\mathrm{HI}$ & B & GU & \\
\hline Balanus eburneus & Barnacle & ST & $\mathrm{HI}$ & B & GU & \\
\hline Balanus reticularis & Barnacle & ST & $\mathrm{HI}$ & $B$ & & \\
\hline Balanus trigonus & Barnacle & & & B & & \\
\hline Balanus venustus & Barnacle & & & $B$ & & \\
\hline Chthamalus proteus & Barnacle & ST & $\mathrm{HI}$ & $B$ & GU & \\
\hline Megabalanus californicus & Barnacle & & & $B$ & & \\
\hline Megabalanus penisularis & Barnacle & & & $B$ & & \\
\hline Argulus japonicus & Copepod & & $\mathrm{HI}$ & & & \\
\hline Psammopsyllus sp. & Copepod & ST & & & & \\
\hline Pseudodiaptomus marinus & Copepod & ST & $\mathrm{HI}$ & & & \\
\hline Teridicola typical & Copepod & ST & & & & \\
\hline Caprella penantis & Amphipod & ST & & B & & \\
\hline Caprella scaura & Amphipod & ST & $\mathrm{HI}$ & B & & \\
\hline Corophium acherusicum & Amphipod & ST & $\mathrm{HI}$ & $B$ & & \\
\hline Corophium baconi & Amphipod & ST & $\mathrm{HI}$ & $B$ & & \\
\hline Corophium insidiosum & Amphipod & ST & $\mathrm{HI}$ & $B$ & & \\
\hline Elasmopus rapax & Amphipod & ST & $\mathrm{HI}$ & B & & \\
\hline Ericthonius brasiliensis & Amphipod & ST & $\mathrm{HI}$ & $B$ & & \\
\hline Grandidierella bispinosa & Amphipod & ST & $\mathrm{HI}$ & & & \\
\hline Grandidierella japonica & Amphipod & ST & $\mathrm{HI}$ & B & & \\
\hline Jassa falcate & Amphipod & & $\mathrm{HI}$ & $B$ & & \\
\hline Leucothoe micronesiae & Amphipod & ST & $\mathrm{HI}$ & B & & \\
\hline Orchestia platensis & Amphipod & ST & & $B$ & & \\
\hline Paracaprella pusilla & Amphipod & ST & & $B$ & & \\
\hline Paraleucothoe flindersi & Amphipod & ST & $\mathrm{HI}$ & $B$ & & \\
\hline Parapleustes derzhavini & Amphipod & ST & & B & & \\
\hline Podocerus brasiliensis & Amphipod & ST & $\mathrm{HI}$ & $B$ & & \\
\hline Stenothoe gallensis & Amphipod & ST & $\mathrm{HI}$ & B & & \\
\hline Stenothoe valida & Amphipod & ST & $\mathrm{HI}$ & B & & \\
\hline Exosphaeroma sp. A & Isopod & ST & $\mathrm{HI}$ & & & \\
\hline Gnorimosphaeroma rayi & Isopod & ST & & & & \\
\hline
\end{tabular}




\begin{tabular}{|c|c|c|c|c|c|c|}
\hline Species & Group & State $^{1}$ & NISBase & Bishop $^{2}$ & Guam & Johnson \\
\hline Ligia exotica & Isopod & ST & $\mathrm{HI}$ & & & \\
\hline Limnoria tripunctata & Isopod & ST & $\mathrm{HI}$ & $B$ & & \\
\hline Mesanthura sp. & Isopod & ST & & $B$ & & \\
\hline Parapsudes pedispinus & Isopod & ST & & B & & \\
\hline Paracereis sculpta & Isopod & ST & $\mathrm{HI}$ & $B$ & & \\
\hline Paralimnoria andrewsi & Isopod & ST & & & & \\
\hline Sphaeroma quoyanum & Isopod & ST & & & & \\
\hline Sphaeroma walkeri & Isopod & ST & $\mathrm{HI}$ & $B$ & & \\
\hline Parapseudes pedispinis & Tanaid & ST & $\mathrm{HI}$ & B & & \\
\hline Holmesimysis costata & Mysid & ST & & & & \\
\hline Nannastacus sp. & Cumacean & ST & & $B$ & & \\
\hline Schereocumella sp. & Cumacean & ST & & & & \\
\hline Anoplodactylus arescus & Pyncnogonid & ST & $\mathrm{HI}$ & $B$ & & \\
\hline Pigrogromitus timsanus & Pyncnogonid & ST & $\mathrm{HI}$ & B & & \\
\hline Atergatopsis immigrans & Crab & ST & $\mathrm{HI}$ & & & \\
\hline Callinectes sapidus & Crab & ST & $\mathrm{HI}$ & B & & \\
\hline Carcinus maenas & Crab & ST & $\mathrm{HI}$ & & & \\
\hline Charybdis helleri & Crab & ST & $\mathrm{HI}$ & & & \\
\hline Glabropilumnus seminudus & Crab & ST & $\mathrm{HI}$ & $B$ & & \\
\hline Nanosesarme minuta & Crab & ST & $\mathrm{HI}$ & B & & \\
\hline Neopanope sp. & Crab & ST & & & & \\
\hline Pachygrapsus fakaravensis & Crab & ST & $\mathrm{HI}$ & & & \\
\hline Panopeus lacustris & Crab & ST & & & & \\
\hline Panopeus pacificus & Crab & ST & $\mathrm{HI}$ & B & & \\
\hline Pilumnus oahuensis & Crab & ST & & B & & \\
\hline Porcellio lamellatus lamellatus & Crab & ST & & & & \\
\hline Rithropanopeus harrisi & Crab & & $\mathrm{HI}$ & & & \\
\hline Schizophrys aspersa & Crab & ST & $\mathrm{HI}$ & & & \\
\hline Scylla serrata & Crab & ST & $\mathrm{HI}$ & $B$ & & \\
\hline Neocaridina denticulate & Shrimp & & $\mathrm{HI}$ & & & \\
\hline Peneaus japonicus & Shrimp & & $\mathrm{HI}$ & & & \\
\hline Peneaus monodon & Shrimp & & $\mathrm{HI}$ & & GU & \\
\hline Penaeus stylirostris & Shrimp & & $\mathrm{HI}$ & & GU & \\
\hline Penaeus vannamei & Shrimp & & $\mathrm{HI}$ & & GU & \\
\hline Upogebia sp. & Shrimp & ST & & & & \\
\hline Gonodactylus aloha & Stomatopod & & $\mathrm{HI}$ & & & \\
\hline Gonodactylus falcatus & Stomatopod & ST & $\mathrm{HI}$ & $B$ & & \\
\hline Caridina weberi & Shrimp & & $\mathrm{HI}$ & & & \\
\hline Aetea truncate & Bryozoan & ST & $\mathrm{HI}$ & B & & \\
\hline Amathia distans & Bryozoan & ST & $\mathrm{HI}$ & $B$ & GU & \\
\hline Bowerbankia gracilis & Bryozoan & ST & & B & & \\
\hline Bowerbankia imbricate & Bryozoan & ST & & $B$ & & \\
\hline Bugula dentate & Bryozoan & ST & $\mathrm{HI}$ & $B$ & & \\
\hline Bugula neritina & Bryozoan & ST & $\mathrm{HI}$ & B & & \\
\hline
\end{tabular}


ERDC/TN ANSRP-05-3

September 2005

\begin{tabular}{|c|c|c|c|c|c|c|}
\hline Species & Group & State $^{1}$ & NISBase & Bishop $^{2}$ & Guam & Johnson \\
\hline Bugula robusta & Bryozoan & ST & $\mathrm{HI}$ & B & & \\
\hline Bugula stolonifera & Bryozoan & ST & $\mathrm{HI}$ & B & & \\
\hline Caulibugula caliculata & Bryozoan & ST & $\mathrm{HI}$ & $B$ & & \\
\hline Caulibugula dendrograpta & Bryozoan & ST & $\mathrm{HI}$ & $B$ & & $\mathrm{~J}$ \\
\hline Cryptosula pallasiana & Bryozoan & ST & & & & \\
\hline Diaperoforma intricate & Bryozoan & & $\mathrm{HI}$ & & & \\
\hline Savignyella lafonti & Bryozoan & ST & $\mathrm{HI}$ & B & & \\
\hline Schizoporella errata & Bryozoan & ST & $\mathrm{HI}$ & $B$ & & \\
\hline Schizoporella unicornis & Bryozoan & ST & $\mathrm{HI}$ & $B$ & & \\
\hline Watersipora edmondsoni & Bryozoan & ST & & $B$ & & \\
\hline Watersipora subtorquata & Bryozoan & ST & & & & \\
\hline Zoobotyrion verticillatum & Bryozoan & ST & & $B$ & & \\
\hline Barentsia sp. & Entoproct & ST & & & & \\
\hline Ascidia sp. A. & Tunicate & & & B & & \\
\hline Ascidia sp. B. & Tunicate & ST & $\mathrm{HI}$ & $B$ & GU & \\
\hline Ascidia sydneiensis & Tunicate & ST & $\mathrm{HI}$ & $B$ & GU & $\mathrm{J}$ \\
\hline Botrylloides simodensis & Tunicate & & $\mathrm{HI}$ & B & & \\
\hline Botryllus sp. & Tunicate & & $\mathrm{HI}$ & & GU & \\
\hline Ciona intestinalis & Tunicate & ST & $\mathrm{HI}$ & $B$ & & \\
\hline Cnemidocarpa Irene & Tunicate & ST & & $B$ & & \\
\hline Corella minuta & Tunicate & ST & $\mathrm{HI}$ & $B$ & & \\
\hline Didemnum candidum & Tunicate & ST & $\mathrm{HI}$ & $B$ & & \\
\hline Didemnum perfucidum & Tunicate & ST & & $B$ & GU & \\
\hline Diplosoma listerianum & Tunicate & ST & $\mathrm{HI}$ & $B$ & GU & $\mathrm{J}$ \\
\hline Eusynstyela aliena & Tunicate & ST & $\mathrm{HI}$ & $B$ & & \\
\hline Eusynstyela hartmeyeri & Tunicate & & & $B$ & & \\
\hline Herdmania momus & Tunicate & ST & $\mathrm{HI}$ & $B$ & & \\
\hline Herdmania pallida & Tunicate & & & $B$ & & \\
\hline Lissoclinum fragilie & Tunicate & & & & GU & \\
\hline Microcosmus exasperatus & Tunicate & ST & $\mathrm{HI}$ & $B$ & GU & $\mathrm{J}$ \\
\hline Phallusia nigra & Tunicate & ST & $\mathrm{HI}$ & $B$ & GU & \\
\hline Polyandrocarpa sagamiensis & Tunicate & ST & $\mathrm{HI}$ & $B$ & GU & \\
\hline Polyandrocarpa zorritensis & Tunicate & ST & $\mathrm{HI}$ & $B$ & & \\
\hline Polyclinum constellatum & Tunicate & ST & $\mathrm{HI}$ & $B$ & GU & \\
\hline Styela canopus & Tunicate & ST & $\mathrm{HI}$ & $B$ & GU & \\
\hline Styela clavata & Tunicate & & & $B$ & & \\
\hline Styela plicata & Tunicate & & & B & & \\
\hline Symplegma brakenhielmi & Tunicate & ST & $\mathrm{HI}$ & $B$ & GU & \\
\hline Symplegma oceania & Tunicate & & $\mathrm{HI}$ & $B$ & & \\
\hline Symplegma reptans & Tunicate & ST & $\mathrm{HI}$ & $B$ & & \\
\hline Anchoa compressa & Fish & $R$ & & & & \\
\hline Anguilla marmorata & Fish & & $\mathrm{HI}$ & & & \\
\hline Centropyge flavissima & Fish & ST & $\mathrm{HI}$ & $B$ & & \\
\hline Cephalopholis argus & Fish & ST & $\mathrm{HI}$ & $B$ & & \\
\hline
\end{tabular}

(Sheet 6 of 7) 
ERDC/TN ANSRP-05-3

September 2005

\begin{tabular}{|c|c|c|c|c|c|c|}
\hline Species & Group & State $^{1}$ & NISBase & Bishop $^{2}$ & Guam & Johnson \\
\hline Cephalopholis urodeta & Fish & & $\mathrm{HI}$ & & & \\
\hline Dorosoma petenense & Fish & ST & $\mathrm{HI}$ & & & \\
\hline Epinephelus fasciatus & Fish & & $\mathrm{HI}$ & & & \\
\hline Epinephelus guttatus & Fish & & $\mathrm{HI}$ & & & \\
\hline Epinephelus hexagonatus & Fish & & $\mathrm{HI}$ & & & \\
\hline Epinephelus irroratus & Fish & & $\mathrm{HI}$ & & & \\
\hline Epinephelus merra & Fish & & $\mathrm{HI}$ & & & \\
\hline Epinephalus spiniger & Fish & $R$ & & & & \\
\hline Fundulus grandis & Fish & & $\mathrm{HI}$ & & & \\
\hline Gambusia affinis & Fish & ST & $\mathrm{HI}$ & & GU & \\
\hline Herklotsichthys quadrimaculatus & Fish & ST & $\mathrm{HI}$ & B & & \\
\hline Lethrinus sp. & Fish & $R$ & & & & \\
\hline Limia vittata & Fish & ST & $\mathrm{HI}$ & & & \\
\hline Lutjanus fulvus & Fish & ST & $\mathrm{HI}$ & $B$ & & \\
\hline Lutjanus gibbus & Fish & ST & $\mathrm{HI}$ & B & & \\
\hline Lutjanus guttatus & Fish & $R$ & $\mathrm{HI}$ & & & \\
\hline Lutjanus kasmira & Fish & ST & $\mathrm{HI}$ & $B$ & & \\
\hline Monopterus albus & Fish & & $\mathrm{HI}$ & & & \\
\hline Moolgarda engeki & Fish & ST & & B & & \\
\hline Morone saxatilis & Fish & $R$ & $\mathrm{HI}$ & & & \\
\hline Mugilgobius cavifrons & Fish & ST & $\mathrm{HI}$ & $B$ & & \\
\hline Mugilgobius parvus & Fish & & $\mathrm{HI}$ & & & \\
\hline Omobranchus ferox & Fish & ST & $\mathrm{HI}$ & & & \\
\hline Omobranchus rotundiceps & Fish & ST & & B & & \\
\hline Oncorhynchus tshawytscha & Fish & $R$ & $\mathrm{HI}$ & & & \\
\hline Oreochromis mossambicus & Fish & ST & & B & & \\
\hline Parablennius thysanius & Fish & ST & $\mathrm{HI}$ & & & \\
\hline Poecilia latipinna & Fish & ST & & B & & \\
\hline Poecilia mexicana & Fish & ST & & B & & \\
\hline Poecilia vittata & Fish & $R$ & & $B$ & & \\
\hline Plecoglossus altivelis & Fish & & $\mathrm{HI}$ & & & \\
\hline Sardinella marquesensis & Fish & ST & $\mathrm{HI}$ & & & \\
\hline Upeneus vittatuus & Fish & ST & $\mathrm{HI}$ & & & \\
\hline Valmugil engeli & Fish & $R$ & $\mathrm{HI}$ & & & \\
\hline \multicolumn{7}{|c|}{ (Sheet 7 of 7} \\
\hline
\end{tabular}

